\title{
LANGUAGE ATTITUDES OF LIMON CREOLE SPEAKERS
}

\author{
Marva Spence Sharpe
}

\begin{abstract}
RESUMEN
Este estudio es un análisis de las actitudes de los hablantes del Criollo Inglés de Limón con respecto a su lengua materna. Una actitud negativa hacia esta lengua es una de las causas fundamentales de la asimilación lingüística que ocurre hoy.
\end{abstract}

\begin{abstract}
The following study is an analysis of Limon Creole speakers' attitudes toward their mother tongue. A non-positive attitude toward Limon Creole is one of the underlying causes for the linguistic assimilation taking place today.
\end{abstract}

\section{Introduction}

This paper is an important part of an ongoing research on language shift in progress among the black population in Port Limon, on the Atlantic Coast, of Costa Rica. I consider that it is almost impossible to argue about language shift without taking into account language attitudes, since, in most of the cases of languages undergoing a shift, it is the small, lower-status linguistic group that shifts to the language of a larger, higher-status group. Lambert and Gardner (1972) have shown how attitudes toward language variety can affect second language learning; Labov (1964) has also shown this in terms of standard dialect learning. Such attitudes, I argue, are also crucial for the maintenance or demise of a language.

There have been many definitions employed in the behavioral sciences for the concept of attitudes. Both Agheyisi and Fishman (1970) and De Fleur and Westie (1963) feel that early definitions of attitudes fall into two categories: those that use a mentalist definition such as Allport's (1935) and those that use a behavioral one. The mentalist definition has to do with mental processes and neural state of readiness, whereas the behavioral definition has to do with social attitudes. Despite the variation in the formal definitions of attitudes, most contemporary social psychologists seem to agree that the characteristic attribute of attitude is its evaluative (pro-con, pleasant-unpleasant) nature. 
In the study of language attitudes among the Limon Creole speakers, it is necessary to understand the socio-historical changes that the speech community has undergone since the late 1940's and how these changes have impacted its current linguistic attitudes.

Olien (1965) identifies three periods in the history of Costa Rica that have had a repercussion on Costa Rican blacks: (1) the colonial period. (2) the construction of the railroad and the presence of the United Fruit Company in the lowlands (1871-1948), and (3) the period of social and legal reforms (1948-1953) marked by the revolution of 1948, the departure of the United Fruit Company and its aftermath.

Port Limon blacks originally came from the West Indies, towards the end of the 1870's, to work on the construction of the railroad which would later become part of the plantation system in the hands of the United Fruit Company. In this period of the history of Limon, English -as spoken by the employers- and Standard Limon English -reserved mainly for religious services and other formal settings within the Limon Creole speech community- were not only the operative linguistic varieties but also the varieties of prestige. Those who did not speak the standard varieties remained at a distinct disadvantage. Blacks, because of their English-based creole mother tongue and their schooling in English, could communicate with their American supervisors, most of whom never bothered to learn Spanish. Blacks were, therefore, favored among the laborers and many were recruited to higher positions because of their language advantage. The acquisition of clerical and managerial jobs was based on educational requirements and on a good command of the English language, which had implications on the emergent shape of social and linguistic relations. Thus language was probably the single most important criterion of status allocation (Purcell 1982).

The period between 1942 and 1953 is considered crucial in the socio-economic transformation of the country. The departure of the United Fruit Company which had heavy repercussions throughout the country, and especially in Limon. Most Jamaican-born blacks who remained in Limon after the departure of the United Fruit Company were either engaged in subsistence farming or were growing cacao. For them, the decline and ultimate demise of the plantation regime meant severe hardships between 1942 and the first opportunity for political participation in 1953.

The new Costa Ricans realized that their socio-economic survival depended, in large measure, on being accepted by the Costa Rican society and that the path to socio-economic mobility was through the national education system. Therefore, Costa Rican citizenship brought along with it a new attitude toward the national language, Spanish. Spanish, which was once despised, was beginning to be seen as one of the most important keys to new opportunities.

\section{Language attributes}

When discussing the attitudes speakers might have toward their language, it is important to cite the attributes that Stewart (1968) considers indispensable to language. Languages having all four attributes are perceived positively. On the other hand, languages having only a few attributes, are highly likely to be perceived negatively. The four attributes are: 
1. Standardization: the codification and acceptance of a designated set of norms for correct usage;

2. Autonomy: consisting of an independent linguistic system not having to be referred to in connection with another language;

3. Historicity: the acceptance of the language variety as one that developed normally over time;

4. Vitality: having an un-isolated community of mother tongue speakers of thatlanguage;

As a creole language, Limon creole exhibits only one of these attributes, vitality.

The competing pressures that Limon Creole is currently undergoing can be seen in the light of the argument set forth by Mackey (1983). He speaks of language power, language pressure and language attraction as three key concepts in what he calls 'geolinguistics'; these forces are, in his view, "ultimately responsible for the life and death of languages."

Mackey sees language power as "the sum total investment in time, money and energy that is made for the purpose of learning a particular language." In other words, the prestige attached to a language and the achievements of the people who speak it will place that language in high acquisition demand. Language attraction depends on the different statuses of languages which become more obvious when languages are in contact. He argues that language pressure arises when there is contact and interpenetration of two or more language groups. At this point, language attraction turns into language pressure.

A similar argument is given by Wardhaugh (1987). According to Wardaugh, the vitality of a language depends on its ability to meet the communicative needs of its people. Therefore, a language perishes because of its loss of usefulness; it might lose political, social, cultural, educational and economic necessity. Conversely, a language flourishes when it offers advantages to the learners.

\subsection{Attitudes Toward Non-standard Varieties}

There is a general negative attitude toward creole languages, as Adler writes:

The usefulness of the pidgin languages and the creoles is beyond doubt. Yet serious studies of these languages is of relatively recent origin, and the reason for this may be the fact that linguists, like everybody else, considered them as beneath serious consideration ...

Todd calls the pidgins and creoles the "poor relations" of the world's languages relegated to the kitchen or the fields,thought to be devoid of cultural potential, dismissed as hotch-potch languages, under-valued and inadequately understood (1977: 31).

Another work that shows negative attitude toward non-standard varieties is Bettoni and Gibbon's study in Australia (1988). The research was conducted among Italian immigrants in Sydney, Australia. In this study, Bettoni and Gibbons show how negative attitudes toward the ethnic language variety - a dialect of Italian - accelerated the shift toward English.

The creole speaker realizes that there is a negative value attached to his stigmatized minority language. In the case of Limon Creole speakers, this negative image is compounded 
by the fact that during the plantation period, language became an important symbol of social status and mobility. The farther away the speaker was from Standard varieties the greater his handicap in the social and economic realm. Thus, language had become a socio-economic denominator in Limon society.

\section{Methodology}

For this study, a questionnaire was designed to capture the attitudes of the Limon Creole speakers toward their language. It was administered to 70 respondents in English or Spanish, ${ }^{1}$ depending on the preference of the respondent. Most of the questions were shortanswer type, with several open-ended items which provide very reliable clues to the function of Limon Creole as representing group identity. The questionnaire was able to capture the professed attitudes along with the subconscious ones.

\section{Respondent's attitudes}

Most people do not realize that they have attitudes toward a language until they are forced to confront or articulate them in some way. They may perceive their speech as being terrible, distorted, terribly careless, sloppy, and horrible. But chances for verbalizing these attitudes are rare, so the forces influencing them are covert and powerful. Our professed attitudes may appear enlightened, but they often differ from the subconscious attitudes which govern our judgement and behavior.

What surfaces from the questionnaire is that the standard varieties are seen by black Limonenses as "proper" or "good" English as compared to the creole which is considered simply an incorrect form of English, broken English or the product of laziness, on the part of the speakers, to produce the standard forms. Aesthetic judgements about Limon Creole are widely shared among the respondents who are very aware that the general local form is stigmatized. Their expressed values are striking, as can be seen in the statements of the following respondents:

\section{9-year old female}

Uno debe tratar de mejorar el inglés criollo.

One should try to better his/her Creole English.

\section{0-year old female}

Debemos de perfeccionar nuestro idioma.

We should improve our language.

\section{1-year old female}

El Limonense debe hacer un esfuerzo por mejorar su idioma.

The Limonense must make an effort to improve his/her language. 
Other respondents not only shared their general feelings toward Limon Creole but they also went on to express how they felt about passing it on to their offspring, as the following two respondents did.

\section{2-year old female}

Es mi idioma y yo lo quiero mucho, pero prefiero mandar a mis hijos a la escuela bilingüe para que ellos aprendan bien el inglés.

It is my language and I love it a lot, but I prefer to send my children to a bilingual school so that they can learn English well.

\section{9-year old female}

Prefiero el inglés estándar. Deseo que mis hijos aprendan el inglés estándar. Y no creo que sea importante que se conserve el criollo limonense sino el inglés estándar.

I prefer Standard English. I want for my children to learn Standard English. I don't think Limon Creole is important to maintain, but Standard English is.

The unquestionable value that is placed on Standard English is demonstrated by the fact that today those who can afford it send their children to private bilingual schools, leaving it up to institutionalized instruction to pass on "good English".

Even though the two respondents below do not make reference to Limon Creole, they eloquently explain the importance of being bilingual and having an excellent command of English.

\section{0-year old female}

El inglés es un idioma universal. Es muy importante. Muchas veces no nos damos cuenta del tesoro que tenemos al hablar dos idiomas. Personalmente creo que debemos hacer un esfuerzo por enseñar a nuestros hijos el inglés.

English is a universal language. It is very important. Many times we ignore the treasure we have in being able to speak two languages. Personally, I believe that we should make an effort to teach our children English.

\section{3-year old female}

Creo que el inglés es un idioma bello y muy importante, deberían de fomentar la enseñanza del mismo pero no el criollo sino el inglés correcto.

I think that English is a beautiful and important language. The teaching of English should be promoted not creole but correct English [my emphasis].

However, it is simply not the case that any one particular language variety is evaluated similarly on various dimensions by all members of that speech community. The following two respondents, for example, expressed great loyalty toward Limon Creole. 


\section{8-year old female}

Es cierto que el inglés criollo de Limón para muchos suena mal. Pero es una tradición tal como el español que se habla aquí como en toda América. No es puro, lo mismo sucede con el inglés.

It is true that the Creole English of Limon sounds bad to many people. But it is a tradition, just as is the Spanish spoken here and in the rest of America. This Spanish is not pure. The same thing happens to English.

Even though the 18-year old respondent above is ready to defend Limon Creole, she starts out her comment by saying that Limon Creole sounds bad to many.

\section{0-year old male}

Sería muy bueno que la gente de Limón hablase muy bien el español y el inglés, pero se debe de conservar nuestra tradición que es el inglés limonense "criollo" o "mek a tell you." Se deben de conservar las tradiciones.

It would be very good if the people of Limon spoke both English and Spanish very well. But we must keep our traditions which is Limon English "creole" or "mek a tell you". Traditions should be kept.

Despite the general admiration for standard English that was expressed above, its use is almost taboo. In general, the use of the standard variety for everyday conversation is taken as being pretentious, insincere and boastful and likely to cause the rejection of the interlocutor. It is felt that the speaker is putting himself above the listener hearer. Within the community therefore, there is a lot of pressure to use the more creole-like varieties, as a sign of solidarity.

However, a known fact in the speech community is that many elders perceive the use of the lower forms of the mesolect and the basilect as a sign of disrespect to them. An anecdote of an elderly man is a good example of this phenomenon. Upon asking him to fill out the questionnaire, he first filled out the section on demographics and proceeded to give the questionnaire a general review. His immediate response was that the choice of the word 'creole' was an insult and that under no circumstance would he respond to such a questionnaire. I tried to explain to him the linguistic meaning of the word creole.

My explanation did not soften his position, but rather, he continued with a long discussion on language choices in the province of Limon. He stated that it is true that a few (my emphasis) speak creole, but that does not mean that they cannot speak the standard form and that there are many who do not speak any creole at all (meaning that they speak the standard form only). I did not succeed in convincing him to answer the questionnaire. I felt that he just became more angry with my labeling the language as creole. I not only lost him as one potential respondent but I also lost the man that was standing next to him who also became very defensive. As a matter of fact, there were quite a few respondents who crossed out the words 'Limon Creole' on the questionnaire and replaced it with 'English'. Their attitude, once again, reflects their subconscious attitudes. The denial of language ability in Limon Creole, by the 78- 
year old man, described above, is not an isolated case. Denial ranges from those who say they do not speak any form of creole to many younger members who claim ability in Spanish only. This is not to say that many of these claims are not real. But in any case, they are another reflection of the negative attitudes toward Limon Creole.

The negative feeling was also manifested by a younger respondent ( 28 years old) who said that he has chosen, since he was 14-years old, not to speak Limon Creole. His reasoning was that if he were able to speak standard English he would. But since he cannot, he has chosen to speak Spanish only.

Many respondents, on the other hand, were very positive toward, and claimed loyalty to Limon Creole. Nevertheless, when called upon to show competence in it, they clearly couldn't speak it.

One 12-year old respondent explained emphatically to me that there was no such thing as a pretty language and an ugly language. He also expressed that Limon Creole was part of "our identity" and "we should speak it." When I asked him why he chose to answer the questionnaire in Spanish, he responded that it was just because Spanish was much easier for him. When I asked why he spoke to his friend, standing next to him, only in Spanish, he responded that it was just a matter of custom. The 12-year old was so eloquent, in his defense of Limon Creole, that I felt compelled to switch to Limon Creole. He continued to speak in Spanish. Finally, I asked him why he was not speaking any Limon Creole. His response was that he could not speak it very well, that his parents and friends spoke Spanish mainly. His case is an example of the power Spanish has acquired. Even though this 12-year old was consistently loyal to Limon Creole, it seems that his speaking ability was not quite fluent Despite the high value given to the standard variety of English, the main goal for black Limonenses, today, is to achieve a crystalline, "accent free" command of the national language. Many feel an accent will be a stigma and will limit an individual's opportunity for social advancement. Below are the responses based on questions which asked respondents to judge the beauty of Limon Creole and Spanish.

\subsection{Aesthetic Judgement and Usefulness of Spanish}

Of a total of sixty-five respondents, eighty-eight percent say that Spanish is a beautiful language that all Costa Ricans should speak. Twelve percent say that they are not sure.

To the statement, "Spanish is an ugly and useless language," ninety-two percent answered negatively; eight percent responded that they are not sure, and only five percent agree that Spanish is ugly and useless.

\subsection{Aesthetic Judgement and Usefulness of Limon Creole}

Unexpectedly, the respondents answered very similarly to the questions about the beauty of Limon Creole as they did on the questions about the beauty of Spanish. Of a total of sixty respondents seventy-three percent said that Limon Creole is a beautiful language, seventeen percent said that they are not sure and only ten percent said that it is not beautiful.

To the statement, "Limon Creole is an ugly and useless language," of the fifty-six respondents, eighty-six percent agreed that Limon Creole is not an ugly and useless language. 
Thirteen percent said that they are not sure, and only one respondent accepted the idea that it is ugly and useless. These responses show that answers to a question of this sort may not portray subconscious language values. It seems that even though the Limon Creole speaker might have negative values toward Limon Creole, this attitude might not surface when directly confronted. Twelve of the respondents who answered positively to the question above also wrote observations similar to the ones chosen below:

Debería de perfeccionarse.

It should be improved.

Sí, pero tenemos que hacer un esfuerzo para mejorarlo.

Yes, but we should make an effort to improve it.

\subsection{Speaking Limon Creole In The Presence Of Monolingual Spanish Speakers}

Giles and Johnson (1981) suggest that if a group perceives itself as having vitality, it, will increase the salience of its members' identity by intensifying the tendency to accentuate group speech. In another study, Giles and Johnson (1987) state that people make a great effort to achieve positive self-image through language choice. Their view is that language choice is a normatively constrained negotiation of personal identity.

This seems to be confirmed by the Limon Creole respondents. When there is a person of the larger community present, there is an inclination to speak the majority language. And, looking more closely at the table below, the respondents under twenty-one years of age are readier than the ones over twenty-one to switch to Spanish in the presence of Spanish monolinguals. The difference between the two age groups is significant at $\mathrm{p}<0.05$. It is important to inform that none of the respondents over age sixty claimed to switch codes in the presence of monolingual Spanish speakers.

\section{Table 1}

Do you speak limon creole even if there is someone present who speaks only Spanish?

$\begin{array}{lccccc} & \mathrm{N} & \text { under } 21 & \mathrm{~N} & 21 \text { and over } & \% \\ \text { Yes } & 4 & 14 & 15 & 36 \\ \text { No } & 24 & 86 & 27 & 64 \\ \text { Total } & 28 & 100 & 42 & 100\end{array}$

$\mathrm{X} 2=3.9, \mathrm{df}=2, \mathrm{p}<0.05$

In general, the sociolinguistic norm for the Limon Creole speaker is to converge when a member of the larger community is present.

But there is variation in language choice under the same circumstances. Not all of the respondents would completely switch to Spanish to accommodate the non-creole speaking interlocutor. Some show a tendency to alternate between both languages depending on the addressee. 


\section{6-year old male}

$\mathrm{Al}$ estar con blancos y negros hablo español para el blanco e inglés para el negro.

Whenever I am with whites and blacks, I speak Spanish for the white person and English for the black person.

\section{8-year old male}

Tiendo a hablar ambos idiomas cuando me encuentro en situaciones donde hay personas que hablan inglés y otras que solamente hablan español.

I tend to speak both languages when I am in situations where there are people who speak English along with others who speak Spanish only.

Others claim that they do not willfully alternate between both languages, but sometimes a phrase or two, in creole, might slip out while they are speaking.

\section{5-year old female}

A veces se me escapa el inglés.

Sometimes English slips out.

\section{7-year old male}

Porque uno nació con esto y a veces se le escapa sin querer.

Because one was born with this ${ }^{2}$ and sometimes it slips out.

Although in a bilingual situation Spanish might be more expected than Limon Creole, speakers can also choose Limon Creole.

\section{6-year old female}

Cuando hablamos algo privado, si es breve.

Whenever we say something private, if it is brief [my emphasis].

\section{0-year old female}

Cuando no quiero que esa persona entienda lo que estoy diciendo.

When I do not want that person to understand what I am saying.

The divergence of the 26-year old female and the 30-year old female above seems to constitute a violation to the choice of the majority of the respondents but such violation reflects that the bilingual speaker may also choose Limon Creole to signal intimacy.

In general, the readiness to switch to Spanish seems to be parallel to numerous studies on language attitudes which have found that the individuals undergoing the shift are more likely to use the incoming language in the presence of one of its speakers. They argue that individuals are evaluated more favorably when they are using the more socially prestigious language. 
In sum, language choice in cross-cultural settings can be crucial because language can symbolize the speaker's self identification. There is evidence, from my observations, that, in most circumstances, the Limon Creole speaker attempts to use Spanish if someone is present who does not speak Limon Creole or English. But in different situations where non-Spanish speakers were present it was not considered necessary to speak Limon Creole. On various occasions, while I was visiting friends who have parents and grandparents with restricted competence in Spanish, the conversations would go on in Spanish, despite the fact that the parents and grandparents were not able to actively participate in the conversation.

\subsection{Importance of Limon Creole To Show Ethnic Identity}

Weinreich (1953) proposes that when culture, ethnicity and language serve to distinguish the group, the ethnic and cultural division becomes salient. His argument that ethnicity and culture override language applies to this case. The Limon Creole speaker does not see it necessary to speak Limon Creole in order to be considered black or to be accepted by black friends. The majority of sixty respondents, ninety-two percent claim that they do not have to speak Limon Creole to be considered black. Similarly, when asked if it is necessary to speak Limon Creole to be accepted by black friends, the majority of the respondents, ninety-two percent of sixty-three say that it is not necessary to speak Limon Creole in order to be accepted by black friends. The responses to both questions are consistent across ages, with the exception of affirmative responses to both questions by respondents over age sixty-five.

\subsection{Attitude Toward Parent's Ability in Limon Creole}

As mentioned earlier, the three structural changes in the history of Costa Rica have brought about three types of blacks: the African, the West Indian and the Costa Rican Black. Therefore, depending on the age of the LC speaker s/he will show traces of Limon Creole in his/her Spanish. In general, the younger the speaker the more native-like is the Spanish. Based on this knowledge the following question was asked:

Do you wish your parents spoke perfect Spanish? Only six of the fifty-eight respondents claim that they do not have any desire for their parents to speak perfect Spanish. This is an example of Limon Creole speakers' great interest in speaking flawless Spanish. Accentedness is seen as somewhat of a handicap, and it reveals a certain degree of anomie.

\subsection{Importance of Maintaining Limon Creole}

There was only one question that directly asked the subjects if they thought it was necessary to maintain Limon Creole. There is strong support for the maintenance of Limon Creole in the community. Of the sixty-eight respondents, ninety percent say that it is important to keep the language. The feelings about maintaining Limon Creole are somewhat conflicting. When asked, "Do you want your children to learn Limon Creole?" forty-eight of fifty-six respondents, eighty-six percent replied "no."

The respondents were also asked if there were some things that sounded better in Creole or in Spanish and if so, what were they? Limon Creole was considered more appropriate 
for intimacy, to express aspects of culture like jokes and folktales. A choice of Spanish was considered more appropriate for political, technical, academic, and work-related matters. Limon Creole encompasses a strong feeling of intimacy, whereas Spanish is more often thought of in terms of status, academic and social advancement.

\section{Conclusion}

Duncan and Meléndez (1981) included in their anthology an article written by Terry Wolfe which reflects some of the attitudes that the black child faces:

The black child frequently hears English in the home; nevertheless, on the streets, there are many more children who speak Spanish. At a tender age, the black child is aware that the language difference is racially related. He soon discovers, usually in the public schools, that Spanish is the prestige language and that English labels him as "different".

I agree wholeheartedly with Wolfe's assessment. And, I would say that twenty-years after Wolfe made this statement, nothing has changed in favor of Limon Creole. The obvious question then is: Will Limon Creole be maintained? This research has attempted to shed some light on the attitudes that underlie the survival or demise of Limon Creole.

In general, the responses to some of the questions show the conflicting language values that the Limon Creole-speaking population is experiencing. On one hand, there is still a great attachment to Limon Creole. Nevertheless, the questionnaire revealed that parents sometimes view Limon Creole as a handicap to their children's education and socio-economic advancement. There are other linguistic values that might pose a threat to the survival of Limon Creole. First, among certain speakers, there is a desire to decreolize or standardize Limon Creole.

Second, some members of the Limon Creole community value their own group identity; nevertheless, others feel the need to function as members of both the smaller and the wider community, and most dangerously for the survival of Limon Creole, many others feel the need to acculturate to the dominant group. Third, most of the respondents thought that speaking Limon Creole was not essential to being identified as black, and there was no need to speak Limon Creole in order to be accepted by members of the LC community. Fourth, at a very young age the LC child develops a desire to conform to the linguistic influence of the wider community, and some parents reported that their children only wanted to speak Spanish at home.

Finally, many researchers of language shift look at the language chosen in the presence of a member of the incoming language, in this case a Spanish speaker, as a one of the indicators that a shift is taking place. Code switching shows Limon Creole speakers 'dual group membership'. Speakers may select from among their linguistic repertoire depending on with which members of the province of Limon they wish to identify. In general, in the presence of a member of the Hispanic community, Spanish is the chosen language.

\section{Notes}

1. Limon Creole is an oral language; therefore, there weren't any questionnaires in that language which, in all event, would have only created much confusion among the respondents. 
2. The word 'this' refers to the Limon Creole.

\section{References}

Adler, Max. 1977. Welsh and Other Dying Languages in Europe: A Sociolinguistic Study Hamburg: Helmut Buske Verlag.

Agheyisi, Rebecca and Joshua Fishman. 1981. "Language Attitudes Studies: A Brief Survey of Methodological Approaches". Anthropological Linguistics. 12: 137-57.

1981. "Language Attitudes Studies: A Brief Survey of Methodological Approaches". Anthropological Linguistics. 12: 137-57.

Duncan, Quince and Carlos Meléndez. 1981. El negro en Costa Rica. San José, Costa Rica: Editorial Costa Rica.

Gal, Susan. 1979. Language Shift Social Determinants in Bilingual Austria. New York: Academic Press.

1978. "Peasant Men Can't Find Wives: Language Change and Sex Roles in a Bilingual Community". Language in Society. 7: 1-16.

Giles, Howard. 1984. "The Dynamics of Speech Accomodation". International Journal of the Sociology of Language. 46.

Labov, William. 1966. The Social Stratification of English in New York City. Washington, D.C.: Center for Applied Linguistics.

Lambert, Wallace, J. Havelka and Robert Gardner. 1959. "Linguistic Manifestations of Biligualism”. American Journal of Psychology. 72: 77-82.

Lambert, Wallace et al. 1960. "Evaluative Reactions to Spoken Languages". Journal of Abnormal and Social Psychology. 50: 44-50, 197-200.

Mackey, William and Donald Cartwright. 1979. Geocoding Language Loss from Census Data. The Hague: Mouton.

Olien, Michael David. 1967. The Negro in Costa Rica: The Ethno-history of an Ethnic Minority in a Complex Society. Diss. University of Oregon.

Purcell, Trevor W. Banana Fallout: Class, Color and Culture among West Indians in Costa Rica. Los Angeles: Center for Afro-American Studies Publications, University of California.

Stewart, William. 1968. "An Outline og Linguistic Typology for Describing multilingualism". Study of the Role of Second Language in Asia, Africa and Latin America. Ed. Frank Rice. Washington: D.C.: Center for Applied Linguistics. 